\title{
Expression of Nrf2 and NF-KB transcription factors in breast cancer and breast fibroadenoma: Insights for a new therapeutic approach
}

\begin{abstract}
Camila Maria Simplicio-Revoredo ${ }^{1}$, Renato de Oliveira Pereira ${ }^{2}$, Mariella de Almeida Melo², Pedro Vitor Lopes-Costa ${ }^{2,3}$, Paulo de Tarso Moura-Borges ${ }^{3}$, Emerson Brandão Sousa ${ }^{3}$, Fidelis Manes Neto², Viriato Campelo², Ione Maria Ribeiro Soares-Lopes ${ }^{2}$, Maria da Conceição Barros-Oliveira ${ }^{1}$, Cleciton Braga Tavares $^{1}$, Alesse Ribeiro dos Santos ${ }^{3}$, Camila Guedes Borges de Araújo², Eid Gonçalves Coelho ${ }^{1}$, Larysse Cardoso Campos-Verdes ${ }^{1}$, Aldenora Oliveira do Nascimento-Holanda², Jackeline Lopes Viana ${ }^{3}$, Maria Liduina Meneses BezerraChaves $^{3}$, Rodrigo José de Vasconcelos-Valença ${ }^{2}$, Lina Gomes dos Santos ${ }^{1}$, Lauro Rodolpho Soares-Lopes ${ }^{2}$, André Luiz Pinho-Sobral ${ }^{3}$, Luiz Henrique Gebrim ${ }^{1}$ and Benedito Borges da Silva ${ }^{1,2,3}$

\footnotetext{
${ }^{1}$ Postgraduate Program, Northeast Biotechnology Network (RENORBIO), Department of Health, Federal University of Piauí, Teresina, Piauí 64000-020, Brazil

${ }^{2}$ Postgraduate Program in Health Sciences, Department of Mastology, Federal University of Piauí, Teresina, Piauí 64000-020, Brazil

${ }^{3}$ Getúlio Vargas Hospital, Department of Mastology, Federal University of Piauí, Teresina, Piauí 64000-020, Brazil

Correspondence to: Benedito Borges da Silva, email: beneditoborges@globo.com
}

Keywords: breast cancer; fibroadenoma; NRF2; NF-KB; immunohistochemistry
\end{abstract}

Received: November 25, $2019 \quad$ Accepted: April 03, $2020 \quad$ Published: May 05, 2020

Copyright: Simplicio-Revoredo et al. This is an open-access article distributed under the terms of the Creative Commons Attribution License 3.0 (CC BY 3.0), which permits unrestricted use, distribution, and reproduction in any medium, provided the original author and source are credited.

\section{ABSTRACT}

Background: Cancer and fibroadenoma are the most common breast tumors in women of reproductive age. Nuclear factor erythroid 2-related factor 2 (Nrf2) and the nuclear factor kappaB (NF-kB) transcription factor play an important role in the inflammatory process and in cell proliferation. However, few studies have analyzed these markers in breast cancer and fibroadenoma in women of reproductive age.

Results: Light microscopy showed a higher concentration of anti-Nrf2 and antiNF-KB-stained nuclei in breast cancer than in fibroadenoma. The mean percentage of stained nuclei for Nrf2 was 7.12 \pm 5.2 and $43.21 \pm 19.83$ in the control and study groups, respectively $(p<0.0001)$. The mean percentage of anti-NF-kB was $10.75 \pm$ 7.09 and $56.14 \pm 21.19$ (mean \pm standard deviation) in the control and study groups, respectively $(p<0.0001)$. Histological grade 3 tumors showed a significantly higher expression of Nrf2 and NF-kB than grade 1 tumors $(p<0.05)$.

Material and methods: This study was approved by the Institutional Review Board of Federal University of Piaui and all patients assigned an inform consent term prior to the study initiation. Nrf2 and NF-kB expression was evaluated by immunohistochemistry in 66 patients, divided into two groups, control (fibroadenoma, $n=36$ ) and study (cancer, $n=30$ ). The data were analyzed using ANOVA test and the statistical significance was established at $\mathbf{p}<0.05$.

Conclusion: Nrf2 and NF-KB expression was significantly higher in breast cancer than in fibroadenoma, in addition to having a greater association with more aggressive tumors. 


\section{INTRODUCTION}

Breast cancer is the most commonly diagnosed malignant neoplasm in women worldwide and, although most prevalent in postmenopausal women, it is estimated that $4.8-5 \%$ of cases occur in young adults under 40 years of age [1]. On the other hand, mammary fibroadenoma is the most common benign lesion in young women of reproductive age, being considered by some as not a tumor, but only an aberration of normal development and involution (ANDI) [2-3]. Despite some controversy over a higher risk for breast cancer in the presence of fibroadenoma, according to the concept of ANDI, this lesion may be considered as a control for breast cancer biomarker studies [4-8].

Despite early diagnosis through mammographic screening, and therapeutic advances, breast cancer is associated with high mortality, requiring a change in strategy when one therapy is ineffective [8]. Changes in therapeutic strategy may be suggested by biomarkers, since alterations induced in biomolecular markers by the administration of drugs linked to the cell proliferation and apoptosis for shorter period of time (2 to 4 weeks) ocurr before any clinical response of the tumor to the treatment $[9,10]$. Likewise, nuclear factor erythroid 2-related factor 2 (Nrf2) and nuclear factor kappa B (NF-kB) transcription factor, related to cell proliferation and apoptosis are associated to malignant progression, poor prognosis and therapy resistance and thus may also suggest therapy changes $[11,12]$.

The Nrf2 pathway represents one of the most important cellular defensive mechanism against xenobiotic/electrophilic and oxidative stress, however the aberrant activation or accumulation of Nrf2 has recently been found to promote cancer development, progression and therapy resistance $[11,13]$. There is increasing evidence to show the complexity of Nrf2 function, in addition to its antioxidant and detoxifying response, implicating it in many other molecular processes including inflammatory responses, metabolic reprogramming, cell proliferation, senescence and survival [14].

The NF- $\mathrm{kB}$ signaling pathway includes a family of transcription factors that play a role in immunity, inflammation and various cancers, including breast cancer [15]. Activation of NF- $\mathrm{kB}$ leads to the induction of target genes that may inhibit apoptosis, interaction with cell cycle regulation, cell invasion, contribute to tumorigenesis, inflammation and metastatic growth, as well as resistance to radio and chemotherapy [12].

However, there are few studies evaluating the immunohistochemical expression of Nrf2 and NF- $\mathrm{\kappa B}$ in women with breast cancer, and to the best of our knowledge no published research has simultaneously evaluated the expression of these biomarkers in women of reproductive age with breast cancer and fibroadenoma. This led us to design of the present study comparing Nrf2 and NF- $\mathrm{kB}$ expression in women of reproductive age with breast cancer and fibroadenoma.

\section{RESULTS}

The characteristics of both groups were homogeneous, except for age and waist circumference (Table 1). Distribution of breast cancer patients according to pathological characteristics showed in relation to the degree of histological differentiation of tumors, a predominance of histological grade 3, as well as the presence of breast tumors larger than $2 \mathrm{~cm}$. Regarding the histological type, invasive ductal carcinoma was present in almost all patients diagnosed with breast cancer. The immunohistochemical profile showed that $50 \%$ of women with breast cancer had positive estrogen receptor (ER) and $50 \%$ had negative estrogen receptor, and there was a predominance of $56.7 \%$ for positive progesterone receptor (PR) and $80 \%$ negative for human epidermal growth factor receptor 2 (HER2). In addition, the luminal molecular subtype B was the most frequent, representing $53.3 \%$ of cases, followed by the triple negative subtype at $26.7 \%$ (Table 2). Light microscopy showed greater concentration of stained nuclei for Nrf2 and NF- $\mathrm{kB}$ in the study group compared to the control group (Figures 1 and 2). The mean percentage of stained nuclei for Nrf2 was 7.12 \pm 5.20 and $43.21 \pm 19.83$ in the control and study groups, respectively $(p<0.0001)$. The mean percentage of stained nuclei for $\mathrm{NF}-\kappa \mathrm{B}$ was $10.75 \pm 7.09$ and $56.14 \pm 21.19$ in the control and study groups, respectively $(p<0.0001)$ (Table 3$)$. Furthermore, Nrf2 expression was significantly higher in histological grade 3 tumors than grade 2 and grade 2 significantly higher than grade 1 , while NF- $\kappa \mathrm{B}$ expression was significantly higher in histological grade 3 tumors than in grade $1(p<0.05)$ (Figures 1 and 2). The box plot in Figures 3 and 4 clearly shows an increase in the mean percentage of histological grade 3 tumors than grade 1 .

\section{DISCUSSION}

There is evidence that Nrf2 and NF- $\mathrm{KB}$ are good biomarkers due to their high expression in invasive breast carcinoma cells. However, few studies have attempted to elucidate the behavior of these proteins in fibroadenoma, a benign tumor that does not increase the risk of developing breast cancer $[15,16]$. This feature makes fibroadenoma an ideal control for determining the expression effect of these proteins on breast cancer and the prognosis in breast cancer.

In the present study, significant overexpression of Nrf2 was observed in breast cancer tissue cells compared to fibroadenoma. To date, only Onodera et al. have investigated $\mathrm{Nrf} 2$ expression in human breast fibroadenoma [16]. These authors evaluated 24 women with benign breast lesions, including papilloma, sclerosing adenosis, usual ductal hyperplasia, and 
Table 1: Patient characteristics

\begin{tabular}{lccc}
\hline Characteristic & $\begin{array}{c}\text { Control group (Fibroadenoma) } \\
(\boldsymbol{n}=\mathbf{3 6}) \text { Mean } \pm \text { DP }\end{array}$ & $\begin{array}{c}\text { Study group } \\
\text { (Breast cancer) } \\
(\boldsymbol{n}=\mathbf{3 0}) \text { Mean } \pm \text { DP }\end{array}$ & $\begin{array}{l}\boldsymbol{p} \text { value } \\
\text { Age }(\mathrm{y})\end{array}$ \\
Menarche age $(\mathrm{y})$ & $32.92 \pm 9.46$ & $40.37 \pm 6.77^{*}$ & 0.0011 \\
BMI $\left(\mathrm{kg} / \mathrm{m}^{2}\right)$ & $12.86 \pm 1.16$ & $13.67 \pm 1.79$ & 0.0820 \\
WC $(\mathrm{cm})$ & $24.20 \pm 4.61$ & $25.70 \pm 3.62$ & 0.1540 \\
\hline
\end{tabular}

${ }^{*}$ There was a statistically significant differences between control and study groups $(p<0.05)$.

Table 2: Distribution of breast cancer patients according to pathological characteristics

\begin{tabular}{|c|c|c|}
\hline \multirow{2}{*}{ Pathological features } & \multicolumn{2}{|c|}{ Breast cancer } \\
\hline & $n$ & $\%$ \\
\hline \multicolumn{3}{|l|}{ Tumour grade } \\
\hline I & 04 & 13.3 \\
\hline II & 12 & 40.0 \\
\hline III & 14 & 46.7 \\
\hline \multicolumn{3}{|l|}{ Tumour size } \\
\hline$<2 \mathrm{~cm}$ & 12 & 40 \\
\hline$\geq 2 \mathrm{~cm}$ & 18 & 60 \\
\hline \multicolumn{3}{|l|}{ Histologycal type } \\
\hline Ductal in situ & 01 & 3.3 \\
\hline Invasive ductal & 29 & 96.7 \\
\hline \multicolumn{3}{|l|}{ Hormone receptor status } \\
\hline \multicolumn{3}{|l|}{ ER } \\
\hline Positive & 15 & 50 \\
\hline Negative & 15 & 50 \\
\hline \multicolumn{3}{|l|}{ PR } \\
\hline Positive & 17 & 56.7 \\
\hline Negative & 13 & 43.3 \\
\hline \multicolumn{3}{|l|}{ HER2 } \\
\hline Positive & 6 & 20 \\
\hline Negative & 24 & 80 \\
\hline \multicolumn{3}{|l|}{ Molecular subtypes } \\
\hline Luminal A & 03 & 10.0 \\
\hline Luminal B & 16 & 53.3 \\
\hline HER2+ & 03 & 10.0 \\
\hline Triple negative & 08 & 26.7 \\
\hline
\end{tabular}

Abbreviations: ER: estrogen receptor, PR: progesterone receptor, HER2: human epidermal growth factor receptor-type 2.

fibroadenoma, and found that $\mathrm{Nrf} 2$ was positive only in one case of fibroadenoma (4\%) while it was positive in $44 \%$ of the women with breast carcinoma. Furthermore, the authors showed that the status of Nrf2 immunohistochemistry in women with mammary carcinoma correlated positively with histological grade, Ki-67 labeling index, p62 immunoreactivity, nicotinamide adenine dinucleotide cofactor $\mathrm{NAD}(\mathrm{P})$ $\mathrm{H}$ immunoreactivity, and quinone oxidoreductase 1 (NQO1). Similarly, in our study, Nrf2 activation was significantly associated with high histological grade. Therefore, Nrf2 overexpression may be an adverse prognostic factor for both relapse and disease-free survival of patients. 
Table 3: Mean percentage of cases with cells expressing Nrf2 and NF- $\mathrm{KB}$ in the control group (fibroadenoma) and study group (breast cancer)

\begin{tabular}{|c|c|c|c|}
\hline & $\begin{array}{c}\text { Control group (Fibroadenoma) } \\
(n=36) \text { Mean } \pm \text { DP }\end{array}$ & $\begin{array}{l}\text { Study group (Breast cancer) } \\
\quad(n=30) \text { Mean } \pm \text { DP }\end{array}$ & $p$ value \\
\hline Nrf2 & $7.12 \pm 5.20$ & $43.21 \pm 19.83^{*}$ & 0.0001 \\
\hline$N F-\kappa B$ & $10.75 \pm 7.09$ & $56.13 \pm 21.19^{*}$ & 0.0001 \\
\hline
\end{tabular}

*There was a statistically significant differences between control and study groups $(p<0.05)$.

$\mathrm{NF}-\mathrm{\kappa B}$ overexpression was also significantly observed in breast cancer tissue cells compared to fibroadenoma. Based on our literature search, only Sarkar et al. has previously investigated the expression of $\mathrm{NF}-\mathrm{\kappa B}$ in human breast fibroadenoma [15]. According to these authors, NF- $\kappa \mathrm{B}$ was undetectable in control group breast tissue patients, whereas activation of NF- $\mathrm{\kappa B}$ was significantly correlated with high grade, large tumor size, high NPI value, ER negativity, PR negativity and HER-2/ neu positivity in breast cancer patients.

Overexpression of NF- $\mathrm{KB}$ implies aggressive tumor biology in breast cancer and may predict tumors with a likely unfavorable prognosis [15]. In our study, $\mathrm{NF}-\kappa \mathrm{B}$ activation was significantly associated with high histological grade corroborating the findings of Sarkar et al. and Shapochka, Zaletok and Gnidyuk [15, 17]. Thus, considering that breast cancer in young women commonly has a higher histological grade, as well as an unfavorable hormonal status, and a higher overall mortality rate compared to older women, the application of NF- $\kappa \mathrm{B}$ as a biomarker may be a promising target for prognosis and therapy of malignant tumors in women of reproductive age $[17,18]$.

In our study, it is noteworthy that although the control (fibroadenoma) and study (breast cancer) groups of women were of reproductive age, the average age of women with breast cancer was significantly higher when compared to those with fibroadenoma. Studies show that breast cancer occurs more often in older women, while fibroadenoma is more common in younger women $[19,20]$. In addition, the measured waist circumference was higher in women with breast cancer than in those with fibroadenoma, which increases the risk of cancerrelated metabolic complications and contributes to a worse prognosis [21].

Based on the results of this study, a new therapeutic approach emerges in breast cancer, since overexpression of Nrf2 and NF- $\mathrm{KB}$ is associated with malignant cells

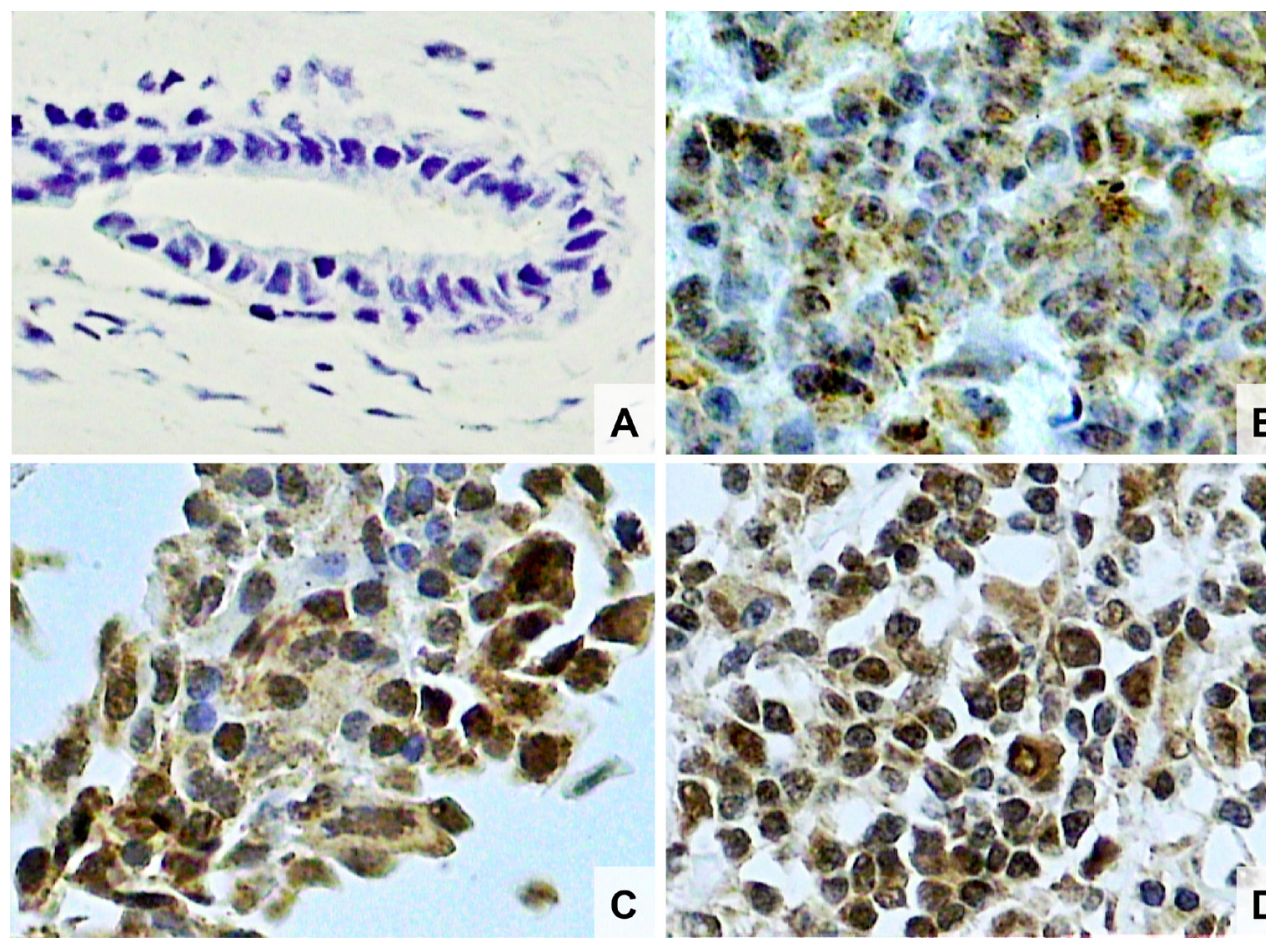

Figure 1: Photomicrographs of histological sections of breast fibroadenoma (A), histological grade 1 breast cancer (B), grade 2 breast cancer $(\mathbf{C})$ and grade 3 breast cancer (D). Note the higher concentration of Nrf2 stained nuclei in breast cancer cells compared to fibroadenoma cells and also a higher concentration of Nrf2 stained nuclei in histological grade 3 than grade 2 and higher in grade 2 than grade 1 breast cancer (original magnifcation $\times 400$ ). 


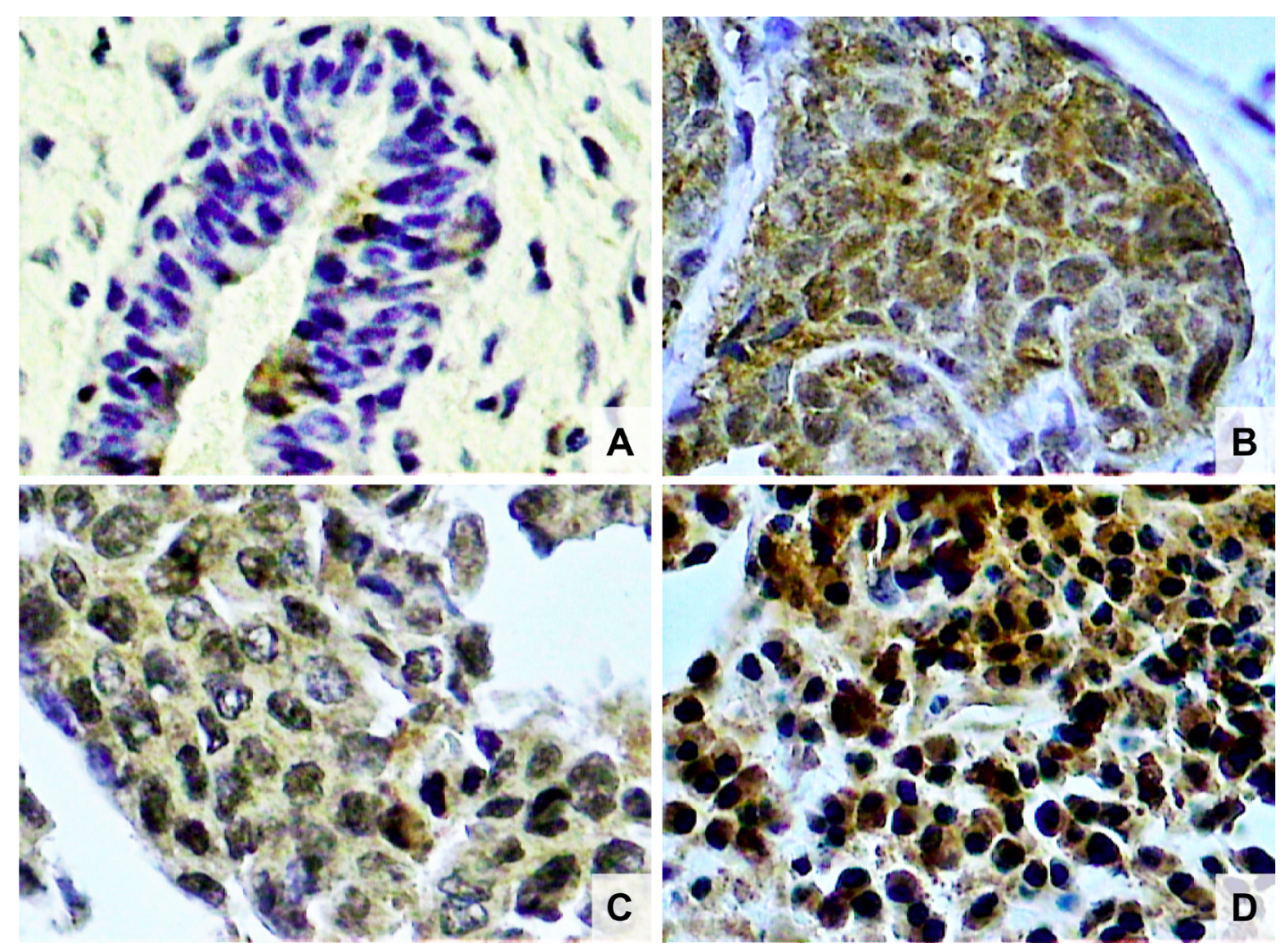

Figure 2: Photomicrographs of histological sections of breast fibroadenoma (A), histological grade 1 breast cancer (B), grade 2 breast cancer $(\mathbf{C})$ and grade 3 breast cancer (D). Note the higher concentration of NF- $\kappa B$ stained nuclei in breast cancer cells compared to fibroadenoma cells, and also a higher concentration of NF- $\mathrm{kB}$ stained nuclei in histological grade 3 than grade 1 breast cancer (original magnifcation $\times 400)$.

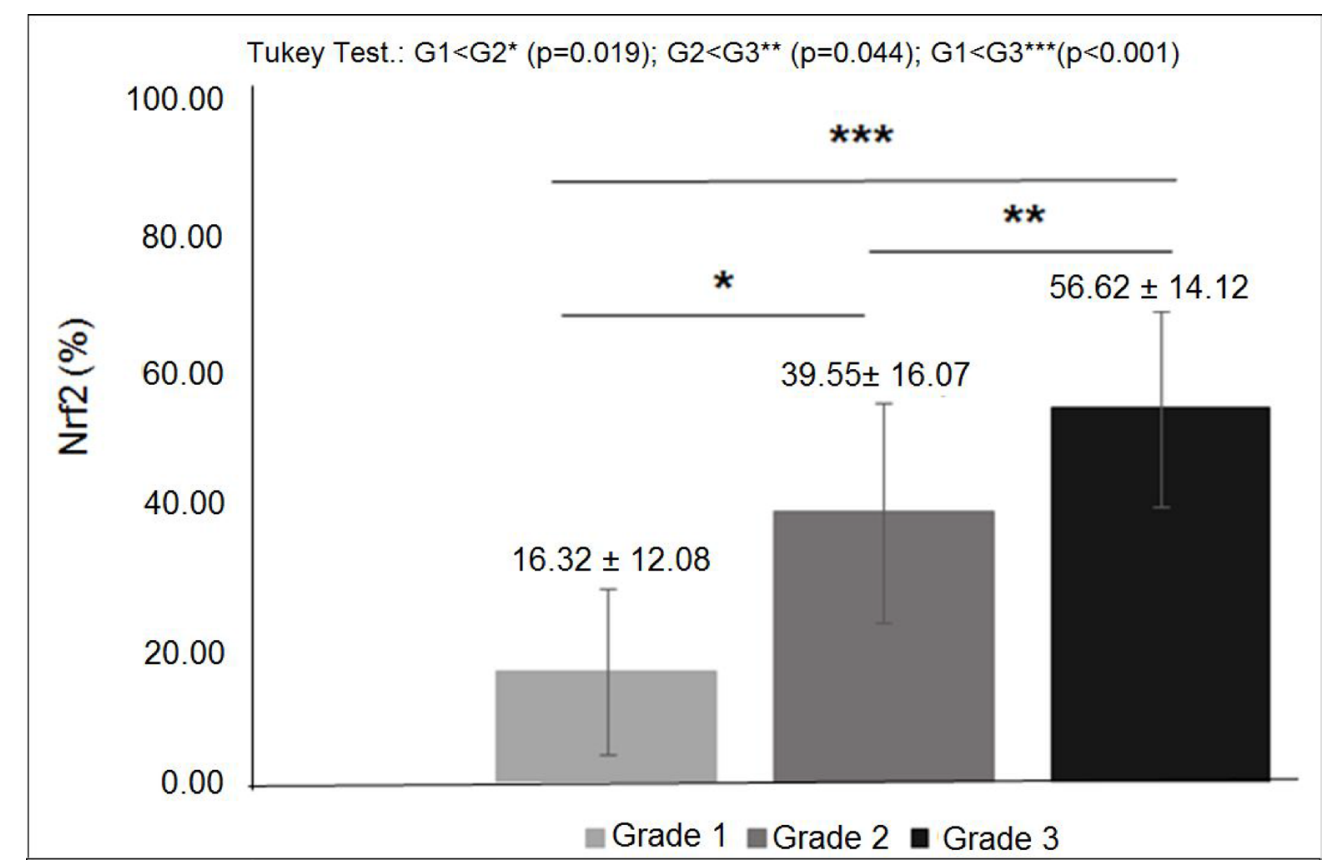

Figure 3: Nrf2 expression in diferent histological grades of breast cancer: mean percentage of Nrf2 expression was significantly higher in histological grade 3 tumors than grade 2 and significantly higher in grade 2 than grade $1(p<0.05)$. 


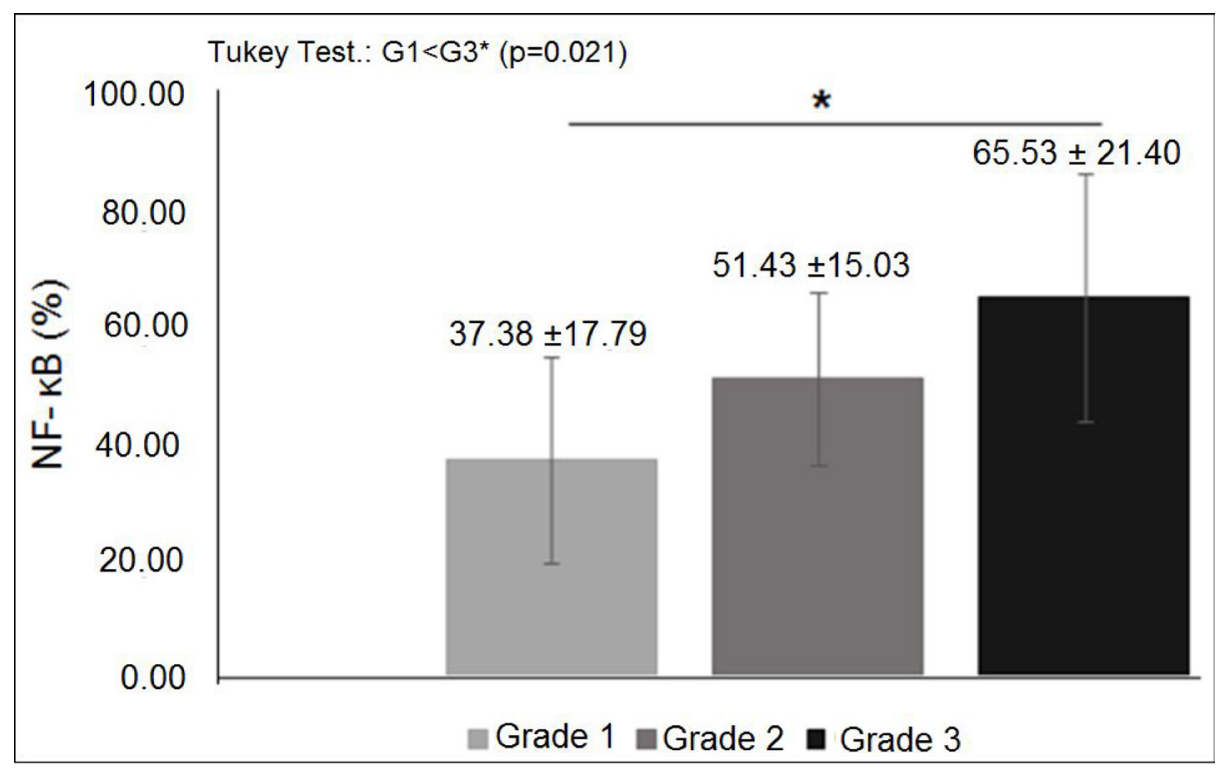

Figure 4: NF- $\kappa \mathrm{B}$ expression in diferent histological grades of breast cancer: mean percentage of NF- $\mathrm{B}$ expression was significantly higher in histological grade 3 tumors than in grade $1(p<0.05)$.

with a higher histological grade and, thus, inhibition of expression of these factors may provide a promising strategy in the treatment of these patients. This builds evidence for the need to conduct intervention studies that evaluate the relationship between inhibition of $\mathrm{Nrf2}$ and $\mathrm{NF}-\mathrm{\kappa B}$ transcriptional pathways and the prognosis of women with breast cancer.

\section{MATERIALS AND METHODS}

\section{Patients}

This study was approved by the Internal Review Board of the Federal University of Piaui (CAAE: 43447015.8.0000.5214). All patients signed a written informed consent form before study initiation. In addition, we confirm that all methods were performed in compliance with current Brazilian laws, in conformity with ethical standards of institutional and national research committees, following the 1964 Helsinki Declaration and its later amendments. A transversal study was carried out, involving 75 premenopausal women with breast tumors. Patients were recruited at the Mastology Clinic of the Getúlio Vargas Hospital, Federal University of Piauí, Brazil, from October 2014 to October 2016. Nine patients were excluded due to technical problems that precluded analysis. Patients were divided into two groups, control group (fibroadenoma, $n=36$ ) and study group (breast cancer, $n=30$ ). All study participants underwent a specialized surgical procedure for histologic and immunohistochemical confirmation of the tumor. The study included premenopausal patients with levels of follicle-stimulating hormone $(\mathrm{FSH})<30 \mathrm{mUI} / \mathrm{ml}$, fibroadenoma or carcinoma of the breast and no previous oncologic treatment.

\section{Immunohistochemistry}

Breast tissue samples fixed in buffered formalin were cut into $3 \mu \mathrm{m}$-thick sections. Sections were deparaffinized in xylol for 5 minutes, dehydrated in absolute ethanol, washed in buffered saline solution at $\mathrm{pH}$ 7.4 for 5 minutes and then treated for 5 minutes with 3\% hydrogen peroxide (H2O2) in buffered solution to block endogenous peroxidase activity. For antigen retrieval, the slides were placed in racks containing $0.21 \%$ citric acid ( $\mathrm{pH}$ 6.0) and heated in a microwave oven for 15 minutes at maximum power. The slides were cooled, and phosphate-buffered saline was added for a cooling period of 20 minutes. Tissue samples were incubated overnight at $4-8^{\circ} \mathrm{C}$ with Anti-Nrf2 rabbit polyclonal antibody (1: 100 dilution) and with anti-NF kappa B / p65 rabbit polyclonal antibody (1: 100 dilution), separately. The slides were rinsed with PBS-Tween and incubated with secondary antibody (anti-mouse BA 2000, Vector Laboratories, Burlingame, CA, USA) for 30 minutes at room temperature. After being washed again with PBSTween, the slides were incubated with reagents from the ABC Elite detection system (PK 6100, Vector Laboratories) for 45 minutes at room temperature. The samples were rinsed once more with PBS-Tween and incubated with DAB (1.0 $\mathrm{ml}$ EnVision FLEX DAB for one drop of chromogen) and for 5 minutes. Finally, the slides were washed with distilled water, counterstained with hematoxylin, stained with ammoniacal solution, dehydrated with absolute ethanol, passed through Coplin jars containing xylol and 
mounted in Permount resin. Cells expressing Nrf2 and $\mathrm{NF}-\kappa \mathrm{B}$ proteins were identified by dark brown staining in the nucleus.

\section{Quantitative method}

Two observers, who were blinded with respect to the patients' identity and had no previous knowledge of any of the cases, performed quantification. It was carried out using a light microscope (Nikon Eclipse E-400, optical microscope, Tokyo, Japan) connected to a color video camera (Samsung digital camera CHC-370 N, Seoul, Korea), which captured the image and transmitted it to a computer equipped with the Imagelab ${ }^{\circledR}$ software program, version 2.3 (Softium Informatica Ltda, Sao Paulo, Brazil) for image analysis.

To determine Nrf2 and $\mathrm{NF}-\kappa \mathrm{B}$ expressions, we counted nuclei of stained cells under a microscope with a magnification of $400 X$. At least 600 cells of the breast epithelium were counted on each slide, in random fields, starting in the area of highest Nrf2 and NF- $\kappa$ B concentration in the cell nucleus, using Processing Software and Image Analysis-Image Lab® (SOFTIUM Informatica Ltda, São Paulo, Brazil). The percentage of stained cells for each case was obtained from the ratio between the number of cells with stained nuclei and unstained nuclei multiplied by 100 (labelling index).

\section{Statistical analysis}

Data were analyzed using SPSS statistical program for Windows 18.0. Data were expressed as frequencies, percentages, measures of central tendency and dispersion. The normality of the data was tested with the Kolmogorov-Smirnov test. The Levene test was used to verify data homogeneity. To compare more than two means between normal and homogenous data, we used Student's t-test and ANOVA. Significant levels were set at $p$ values $\leq 0.05$.

\section{Ethics approval}

This study was approved by the Internal Review Board of the Federal University of Piaui (CAAE: 43447015.8.0000.5214). All patients signed a written informed consent form before study initiation.

\section{Author contributions}

C.M.S.R., R.O.P., M.A.A., P.V.L.C, R.J.V.V. study conception, data analysis, writing of the manuscript; P.T.M.B., E.B.S., F.M.N., V.C., I.M.R.S.L., M.C.B.O., C.B.T., A.R.S., L.G.S., A.L.P.S., M.L.M.B.C. data collection. L.R.S.L., C.G.B.A., E.G.C., L.C.C.V., A.O.N.H., J.L.V., L.H.G statistical analysis; BBS: study conception, writing of the manuscript, supervision of the work. All authors read and approved the final manuscript.

\section{ACKNOWLEDGMENTS}

The authors thank the patients who participated in the current study and the Postgraduate Program of the Federal University of Piauí, Brazil.

\section{CONFLICTS OF INTEREST} interests.

The authors declare that they have no competing

\section{FUNDING}

This study was not funded.

\section{REFERENCES}

1. Encinas G, Sabelnykova VY, de Lyra EC, Hirata Katayama ML, Maistro S, de Vasconcellos Valle PW, de Lima Pereira GF, Rodrigues LM, de Menezes Pacheco Serio PA, de Gouvêa AC, Geyer FC, Basso RA, Pasini FS, et al. Somatic mutations in early onset luminal breast cancer. Oncotarget. 2018; 9:22460-79. https://doi.org/10.18632/ oncotarget.25123. [PubMed]

2. Ciurea AI, Herţa HA, Iacoban CG, Fetica B, Rogojan L, Ciortea CA. Fibroadenomas and breast carcinoma: a possible answer to a frequently asked question. A pictorial essay. Med Ultrason. 2018; 20:385-91. https://doi. org/10.11152/mu-1408. [PubMed]

3. Hughes LE, Mansel RE, Webster DJ. Aberrations of normal development and involution (ANDI): a new perspective on pathogenesis and nomenclature of benign breast disorders. Lancet. 1987; 2:1316-19. https://doi.org/10.1016/S01406736(87)91204-9. [PubMed]

4. Dupont WD, Page DL. Risk factors for breast cancer in women with proliferative breast disease. N Engl J Med. 1985; 312:146-51. https://doi.org/10.1056/ NEJM198501173120303. [PubMed]

5. McDivitt RW, Stevens JA, Lee NC, Wingo PA, Rubin GL, Gersell D, and The Cancer and Steroid Hormone Study Group. Histologic types of benign breast disease and the risk for breast cancer. Cancer. 1992; 69:1408-14. https://doi. org/10.1002/1097-0142(19920315)69:6<1408::AID-CNCR 2820690617>3.0.CO;2-C. [ [PubMed]

6. Nassar A, Visscher DW, Degnim AC, Frank RD, Vierkant RA, Frost M, Radisky DC, Vachon CM, Kraft RA, Hartmann LC, Ghosh K. Complex fibroadenoma and breast cancer risk: a Mayo Clinic Benign Breast Disease Cohort Study. Breast Cancer Res Treat. 2015; 153:397-405. https://doi.org/10.1007/s10549-015-3535-8. [PubMed]

7. Worsham MJ, Raju U, Lu M, Kapke A, Botttrell A, Cheng J, Shah V, Savera A, Wolman SR. Risk factors for breast cancer from benign breast disease in a diverse population. 
Breast Cancer Res Treat. 2009; 118:1-7. https://doi. org/10.1007/s10549-008-0198-8. [PubMed]

8. Sampaio FA, Martins LM, Dourado CS, Revoredo CM, Costa-Silva DR, Oliveira VA, Alves-Ribeiro FA, Silva BB. A case-control study of Metallothionein-1 expression in breast cancer and breast fibroadenoma. Sci Rep. 2019; 9:7407. $\quad$ https://doi.org/10.1038/s41598-019-43565-0. [PubMed]

9. Dowsett M, Smith IE, Ebbs SR, Dixon JM, Skene A, Griffith C, Boeddinghaus I, Salter J, Detre S, Hills M, Ashley S, Francis S, Walsh G, A'Hern R. Proliferation and apoptosis as markers of benefit in neoadjuvant endocrine therapy of breast cancer. Clin Cancer Res. 2006; 12:1024s30s. https://doi.org/10.1158/1078-0432.CCR-05-2127. [PubMed]

10. Lopes-Costa PV, dos Santos AR, dos Santos LG, da Silva BB. Evaluation of Ki-67 and Bcl-2 antigen expression in breast carcinomas of women treated with raloxifene. Cell Prolif. 2010; 43:124-29. https://doi.org/10.1111/j.13652184.2009.00664.x. [PubMed]

11. Panieri E, Saso L. Potential applications of NRF2 inhibitors in cancer therapy. Oxid Med Cell Longev. 2019; 2019:8592348. https://doi.org/10.1155/2019/8592348. [PubMed]

12. Sarkar DK, Jana D, Patil PS, Chaudhari KS, Chattopadhyay BK, Chikkala BR, Mandal S, Chowdhary P. Role of NF- $\kappa$ B as a Prognostic Marker in Breast Cancer: A Pilot Study in Indian Patients. Indian J Surg Oncol. 2013; 4:242-47. https://doi.org/10.1007/s13193-013-0234-y. [PubMed]

13. Kitamura H, Motohashi H. NRF2 addiction in cancer cells. Cancer Sci. 2018; 109:900-11. https://doi.org/10.1111/ cas.13537. [PubMed]

14. Zhang HS, Du GY, Zhang ZG, Zhou Z, Sun HL, Yu XY, Shi YT, Xiong DN, Li H, Huang YH. NRF2 facilitates breast cancer cell growth via HIF1 $\alpha$-mediated metabolic reprogramming. Int J Biochem Cell Biol. 2018; 95:85-92. https://doi.org/10.1016/j.biocel.2017.12.016. [PubMed]
15. Chang J, Zhang Y, Li Y, Lu K, Shen Y, Guo Y, Qi Q, Wang $\mathrm{M}$, Zhang S. NrF2/ARE and NF- $\kappa \mathrm{B}$ pathway regulation may be the mechanism for lutein inhibition of human breast cancer cell. Future Oncol. 2018; 14:719-26. https://doi. org/10.2217/fon-2017-0584. [PubMed]

16. Onodera Y, Motohashi H, Takagi K, Miki Y, Shibahara Y, Watanabe M, Ishida T, Hirakawa H, Sasano H, Yamamoto M, Suzuki T. NRF2 immunolocalization in human breast cancer patients as a prognostic factor. Endocr Relat Cancer. 2014; 21:241-52. https://doi.org/10.1530/ERC-13-0234. [PubMed]

17. Shapochka DO, Zaletok SP, Gnidyuk MI. Relationship between NF-kB, ER, PR, Her2/neu, Ki67, p53 expression in human breast cancer. Exp Oncol. 2012; 34:358-63. [PubMed]

18. Erić I, Petek Erić A, Kristek J, Koprivčić I, Babić M. Breast cancer in young women: pathologic and immunohistochemical features. Acta Clin Croat. 2018; 57:497-502. https://doi.org/10.20471/acc.2018.57.03.13. [PubMed]

19. Nazario AC, Rrego MF, Oliveira VM. Benign breast masses: a review on diagnosis and management. Rev Bras Ginecol Obstet. 2007; 29:211-19. https://doi.org/10.1590/ S0100-72032007000400008.

20. Martins LM, de Melo Escorcio Dourado CS, CamposVerdes LM, Sampaio FA, Revoredo CM, Costa-Silva DR, da Conceição Barros-Oliveira M, de Jesus Nery Junior E, do Rego-Medeiros LM, Gebrim LH, AlvesRibeiro FA, Rodrigues GP, Chagas DC, et al. Expression of matrix metalloproteinase 2 and 9 in breast cancer and breast fibroadenoma: a randomized, double-blind study. Oncotarget. 2019; 10:6879-84. https://doi.org/10.18632/ oncotarget.27347. [PubMed]

21. White AJ, Nichols HB, Bradshaw PT, Sandler DP. Overall and central adiposity and breast cancer risk in the Sister Study. Cancer. 2015; 121:3700-08. https://doi.org/10.1002/ cncr.29552. [PubMed] 